\title{
Satisfaction of Residents Towards Internal Courtyard Buildings
}

\author{
Adi Ainurzaman Jamaludin ${ }^{1}$, Hazreena Hussein ${ }^{2}$, and Kauthar Md. Tahir ${ }^{1}$ \\ ${ }^{1}$ Institute of Biological Sciences, Faculty of Science, University of Malaya, 50603 Kuala \\ Lumpur, Malaysia \\ ${ }^{2}$ Department of Architecture, Faculty of Built Environment, University of Malaya, 50603 Kuala \\ Lumpur, Malaysia
}

*adiainurzaman@um.edu.my

Received :2 December $2018 \quad$ Final Version Received: 28 December 2018

\begin{abstract}
Residential buildings that were designed with internal courtyards offer a comfortable and pleasant indoor environment. Past research on the benefits of internal courtyards have been scientifically proven, however, the results seemed disreputable in terms of its satisfaction by occupants of a building. A survey using a set of questionnaire was conducted at two selected residential colleges in the University of Malaya to gauge the satisfaction level of residents towards an existing internal courtyard. It is evident that the majority of respondents at both colleges have given positive feedback on the satisfaction of the building layout quality, comfort level in terms of the natural daylighting, thermal comfort and indoor air quality as well as the degree of their work productivity. These findings indicate that the internal courtyard is relevant to be applied when designing a building, particularly low-rise residential buildings in the equatorial climate region.
\end{abstract}

Keywords: Comfort level, Internal courtyard, Likert-scale, Residential building

\section{INTRODUCTION}

Courtyard in residential buildings is commonly applied for the purpose of promoting comfortable indoor environments by offering natural ventilation and daylighting into buildings. In the Middle East, courtyards provide the much-needed security and privacy for residents while reducing the infiltration of hot and dusty winds into the rooms with tall walls that build around the courtyard (Safarzadeh \& Bahadori, 2005). Courtyard creates a micro-environment that provides very pleasant living spaces with the presence of healing elements such as trees, flowers, shrubs and a pool of water (Safarzadeh \& Bahadori, 2005; Almhafdy et al., 2013a).

The influence of a courtyard on the thermal condition has a strong reliance on the envelope opening and exhibits a better energy performance in hot-dry and hot-humid climates (Sadafi et al., 2011; Zakaria et al., 2015; Aldawoud, 2008). According to Almhafdy et al. (2013a), the development of a courtyard has moved forward into the era of sustainability and green architecture, where the courtyard configurations can be classified into four. There are:
- Cluster courtyard

a) Multiple : the design of the building creates four fullyenclosed courtyards.

b) Spinal : More than one courtyard is attached to the building's central circulation route.

- Open courtyard : Group of buildings frame open spaces into the courtyards.

- Closed courtyard : The courtyard is fully enclosed.

- Complex/Interlinked courtyard : Courtyards are located on different floors and serving different purposes.

Generally, the U-shape of a courtyard with an aspect ratio of $1: 2$, which is considered as a rectangle has a better performance in terms of the thermal comfort as compared to the U-shape of a courtyard with an aspect ratio of 1:1, which is considered as a square (Almhafdy et al., 2015). 
The successful attribute of a courtyard in building designs is not limited to providing comfortable indoor environments and efficient use of electricity. It should be extended to the residents' satisfaction to understand the mutual interactive process between the building and the user's needs (Khalil et al., 2008). Thus, the wastage of maintenance and operating costs can be evaded as the residents' actual needs are determined proximately. Furthermore, it would improve the quality of the facilities, morale and work performance of the residents (Hassanain et al., 2010). According to Ilesanmi (2010), the residents' perception of a proper residential environment cannot be ignored at the policy, planning, design and implementation levels where satisfaction with the physical environment of the residence is the most powerful predictor of residential satisfaction. Thus, the notable design features can be repeated in future development, and any redundant or unnecessary building features will be eliminated. In order to ensure that the building continues to deliver appropriate levels of satisfaction to the end-user, the critical evaluation in terms of the satisfaction should not only occur in a facility once it is constructed and occupied, but it should also be carried out throughout the entire building delivery cycle (Preiser, 1995; Turpin-Brooks \& Viccars, 2006). It is necessary to focus on the most relevant issues rather than to attempt to analyse everything and risk an overload of data (Hadjri \& Crozier, 2009).

Satisfaction is a comparison of the user's expectations versus perception of experience (Shahzad et al., 2015). According to Ogunjuyigbe et al. (2017), satisfaction is quantifiable, fuzzy rather than crisp, comparative and relative. Satisfaction assessment is achievable based on the performance or perception through real-time experience, overall experience, simulated experience and cognitive experience (Shafaghat et al., 2016). Five-point Likert scaling method is one of the user satisfaction measurement based on real-time experience and considered as one of the most famous scaling methods as it can be modified depending on the purpose of research with further statistical analysis (Shafaghat et al., 2016; Harpe, 2015).

We have a shortage of residents' satisfaction studies on the internal courtyard at residential buildings, particularly in tropical climate regions. Most of the reported studies are experimental studies that focus on the advantages and disadvantages of the internal courtyard in terms of natural ventilation and daylighting, either through the field measurement or simulation (Sadafi et al., 2011; Zakaria et al., 2015; Almhafdy at al., 2015; Aldawoud \& Clark, 2008; Ghaffarianhoseini et al., 2015). Therefore, the aim of this research is to evaluate the residents' satisfaction level of two existing residential colleges with an internal courtyard arrangement, with the purpose of justifying the relevance of the internal courtyard in the building design, particularly low-rise residential buildings.

\section{RESEARCH METHODOLOGY}

A survey using a set of questionnaire on residents' satisfaction was conducted based on a study by Jamaludin et al. (2014). There are only six questions covering different performance indicator including building layout, the overall quality of the building, the thermal comfort and indoor air quality, the quality of lighting (natural daylight), the overall comfort level and the influence of overall building conditions on the degree of work productivity. The questionnaire uses a Likert Scale format where each number responds to a specific scale as listed below;

- $\quad-2$ : very poor / too dark / very uncomfortable / very dissatisfied / much decrease,

- -1 : poor / dark / uncomfortable / dissatisfied / decrease

- 0 : fair / neither / no changes

- $\quad+1$ : good / bright / comfortable / satisfied / increased

- $\quad+2$ : very good / too bright / very comfortable / very satisfied / much increased

The questionnaires were distributed randomly to all residents with the minimum feedbacks relying on $95 \%$ of confident level and $\pm 5 \%$ margin of error from the overall population. The calculation of the sample size is based on the formula (Yamane, 1967):

$$
n=N / 1+N(e)^{2}
$$

$\mathrm{n}$ is the sample size, $\mathrm{N}$ is the population size and $\mathrm{e}$ is the level of precision. The respondents were asked to give their response based on their general experience and not referred to a specific internal courtyard. A statistical software package has been used to analyse all the questionnaires collected. 


\section{BUILDING DESCRIPTION}

\subsection{KD-1}

KD-1 is the $5^{\text {th }}$ Residential College known as Dayasari Residential College. It is located at the University of Malaya, Kuala Lumpur. Built in 1966, this residential college was able to accommodate 847 residents at any single time. It consists of five residential blocks with three-floor levels each, excluding a ground floor. The site plan and typical floor plan of the KD-1 are presented in Figures 1 and 2.

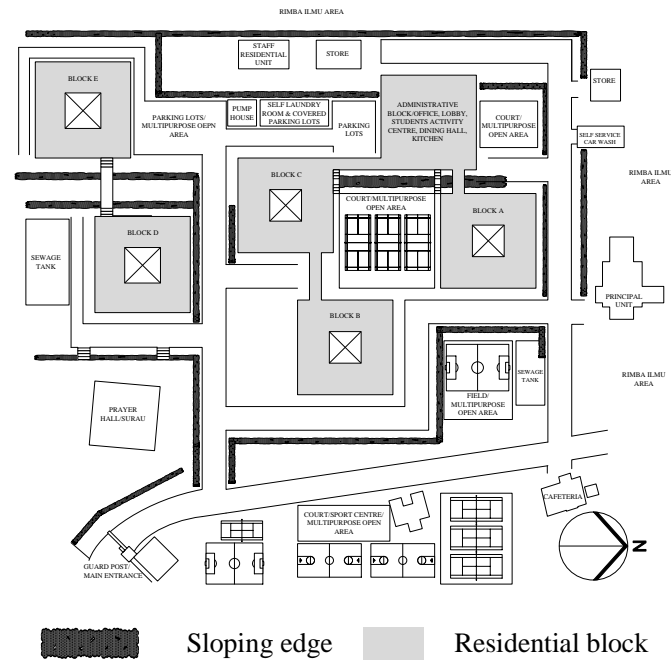

Figure 1: Site plan of KD-1

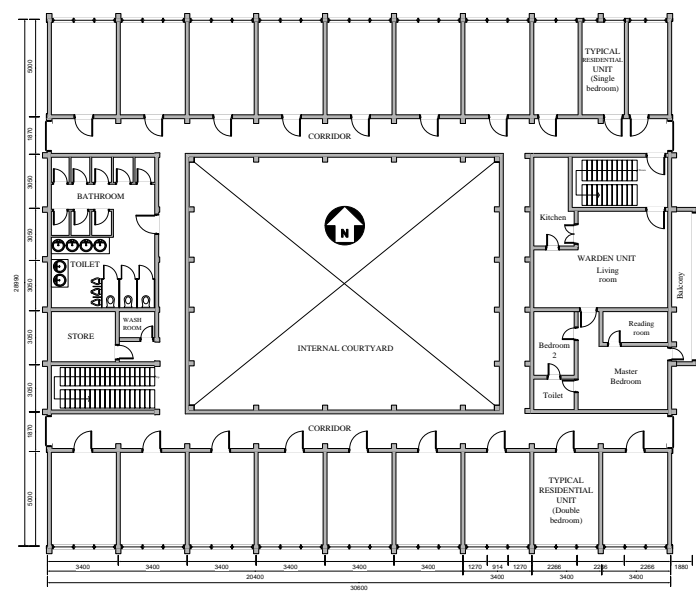

Figure 2: Typical floor plan of KD-1

The residential building is designed with an internal courtyard arrangement and rectangle shape of the building's floor plate. The total floor area is $18,212.51 \mathrm{~m}^{2}$, while the room's floor area and volume are $16.35 \mathrm{~m}^{2}$ and $45.78 \mathrm{~m}^{3}$, as the typical room dimension is $4.74 \mathrm{~m}$ (l) $\times 3.45 \mathrm{~m}(\mathrm{w}) \times 2.80 \mathrm{~m}(\mathrm{~h})$. Most of the rooms, especially the ones at the middle of the floor are directly facing the internal courtyard. This promotes natural ventilation and daylighting inside the rooms through transoms on top of the entrance door and wall. The area of the internal courtyard is $239.88 \mathrm{~m}^{2}$, planted with grass and shrubs. There is a small hut, known as gazebo that functions as a social or engagement space for the residents. With regard to the enclosure and façade design, there are centre pivots and awning window design with tinted glasses in each room. The different types of windows help to channel outside air/wind from a different angle while giving residents full control towards daylighting besides the large horizontal overhangs along the wall with windows. The characteristics of the KD-1 are visualised through the standard regular photographs presented in Figure 3.

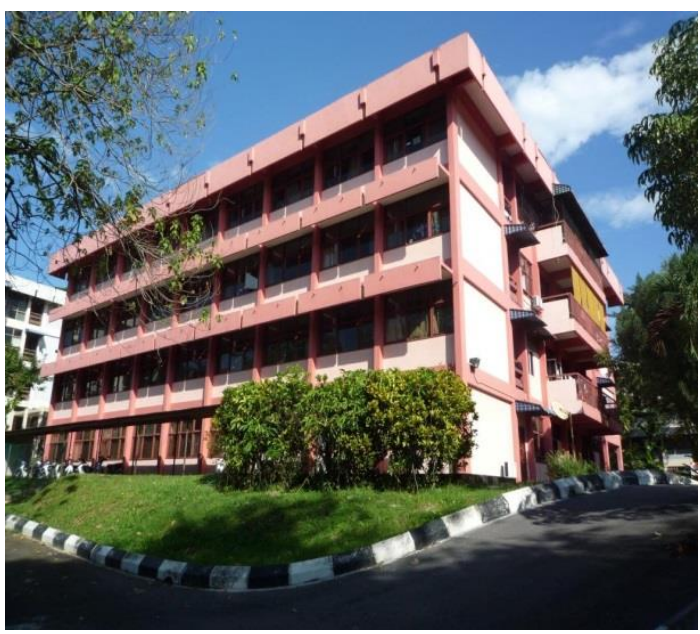

(a) Built-form configuration, enclosure and facade design - Large horizontal overhangs along the wall with windows

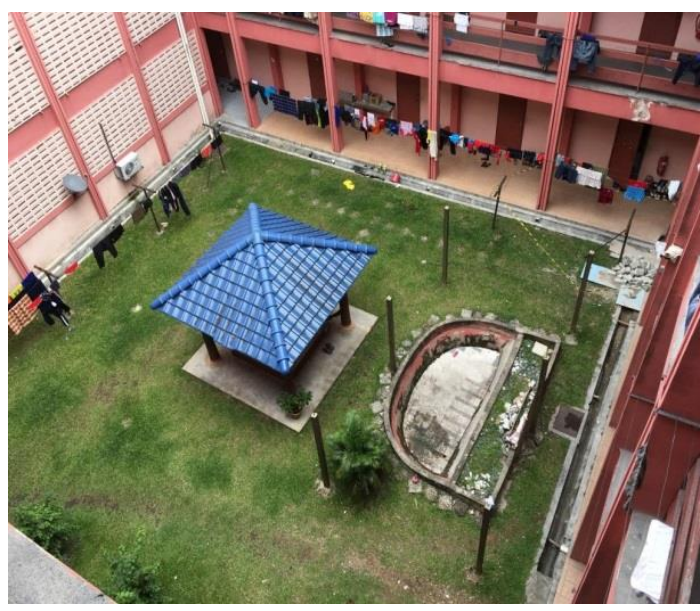

(b) Internal courtyard in the middle of residential building 


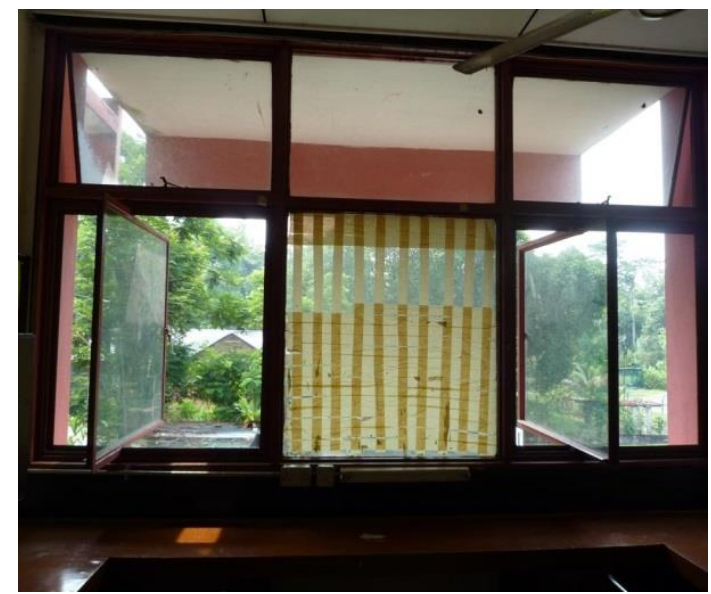

(c) Centre pivots \& awning window design with tinted glass

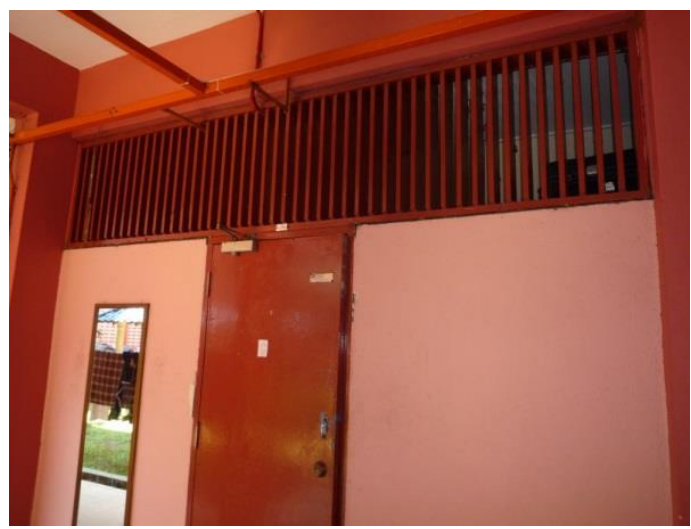

(d) Transom/fixed opening over the doorway of residential unit.

Figure 3: The characteristics of KD-1

\subsection{KD-2}

KD-2 is the $11^{\text {th }}$ Residential College known as the Ungku Aziz Residential College. Located at the University of Malaya, it was established in 1998. This residential building provides comfortable and spacious rooms with 897 residents. The KD-2 only consists of four residential blocks with three-floor levels each, excluding a ground floor.

The site plan and typical floor plan of the KD-2 are presented in Figures 4 and 5. Similar to the KD-1, KD-2 was designed with an internal courtyard arrangement in an L-shape of the building's floor plate. The total floor area is $34,305.32 \mathrm{~m}^{2}$. The room's floor area and volume are $20.00 \mathrm{~m}^{2}$ and $57.40 \mathrm{~m}^{3}$, respectively, whereas the room dimension is $5.0 \mathrm{~m}(\mathrm{l}) \mathrm{x} 4.0 \mathrm{~m}(\mathrm{w}) \mathrm{x}$ $2.87 \mathrm{~m}(\mathrm{~h})$. There are four rooms with the entrance facing each other and forming a cubicle. There are five cubicles with one collective space on each floor. Each cubicle is connected through an open corridor that faces the internal courtyard. The total area of the internal courtyard is $303.92 \mathrm{~m}^{2}$ for blocks A and $\mathrm{B}$, and $269.12 \mathrm{~m}^{2}$ for blocks $\mathrm{C}$ and $\mathrm{D}$. The internal courtyard area is planted with grass and shrubs.

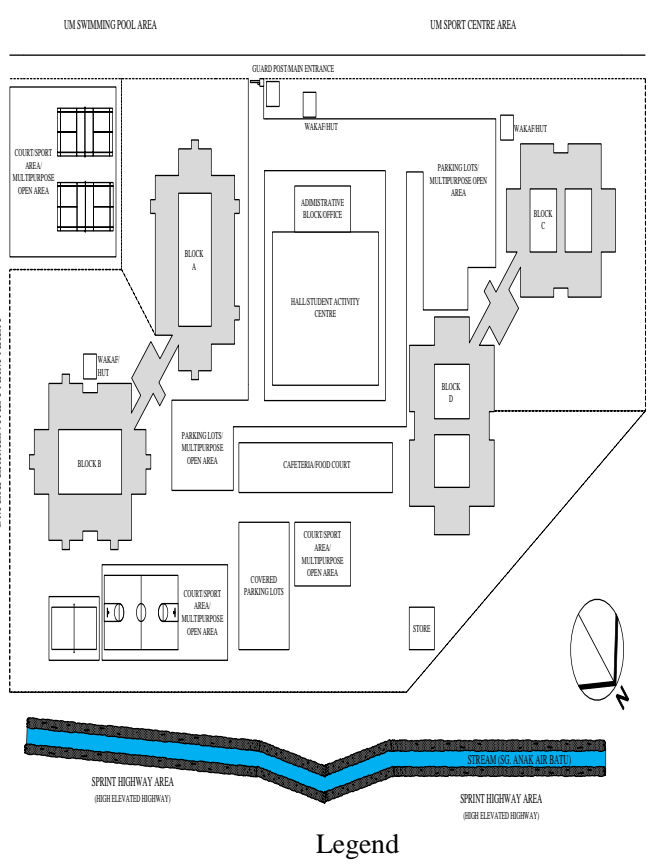

Sloping edge

Residential block

Figure 4: Site plan of KD-2

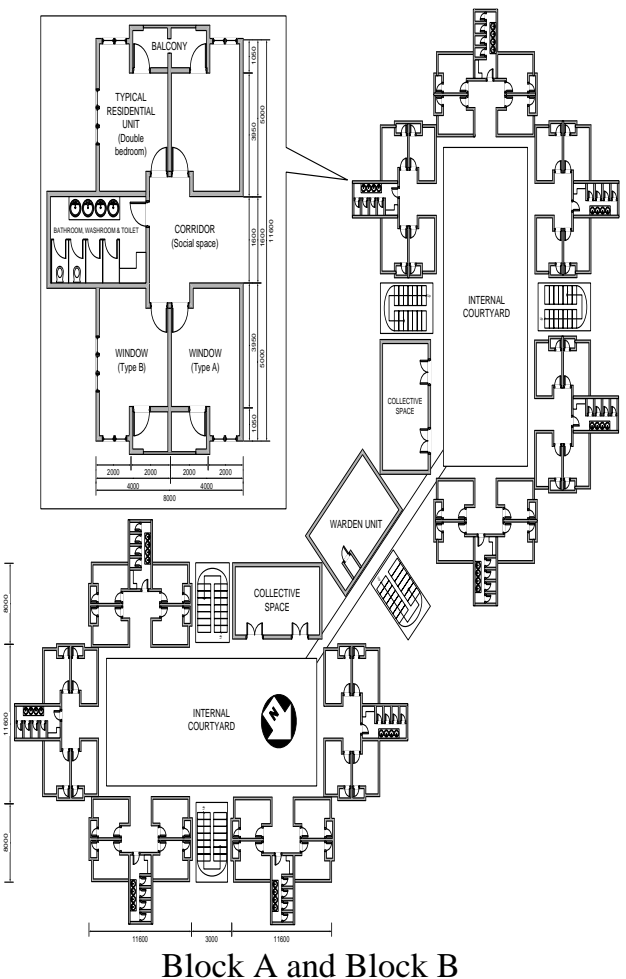




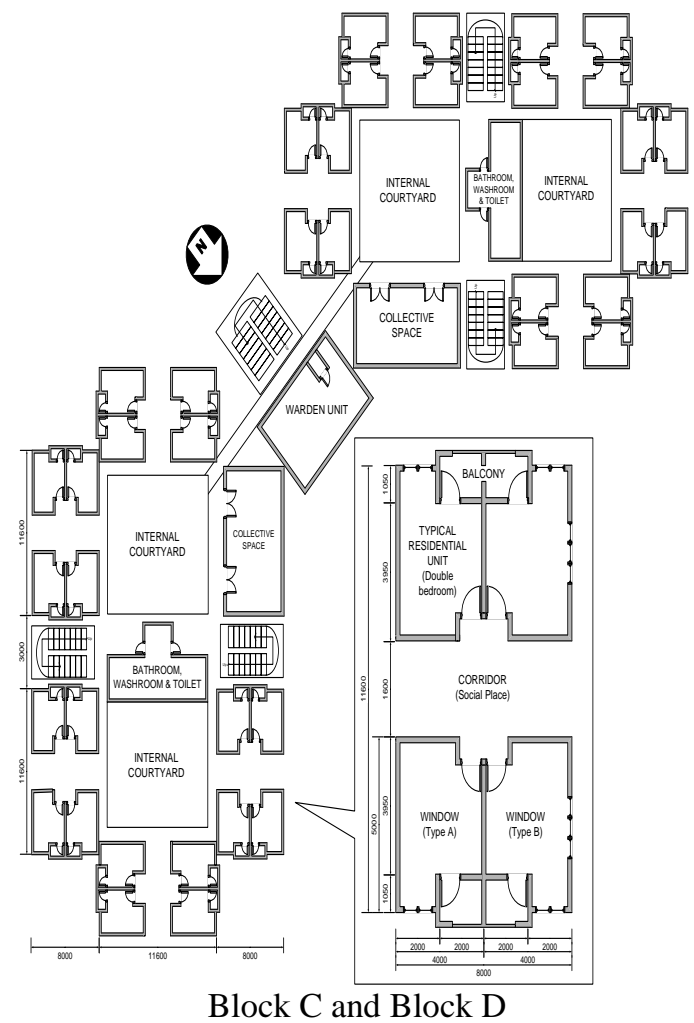

Figure 5: Typical floor plan of KD-2

In providing a control to the residents over the natural ventilation and daylighting, each room was designed with a balcony and two different types of windows. They are casement and turn windows with tinted glass. The characteristics of the KD-2 are visualised through the standard regular photographs that are presented in Figure 6.

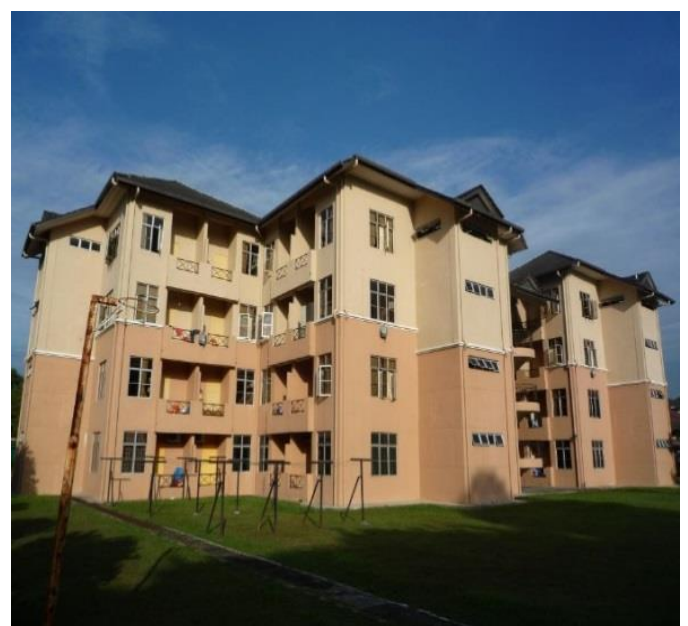

(a) Built-form configuration, enclosure and facade design - Large horizontal overhangs along the wall with windows

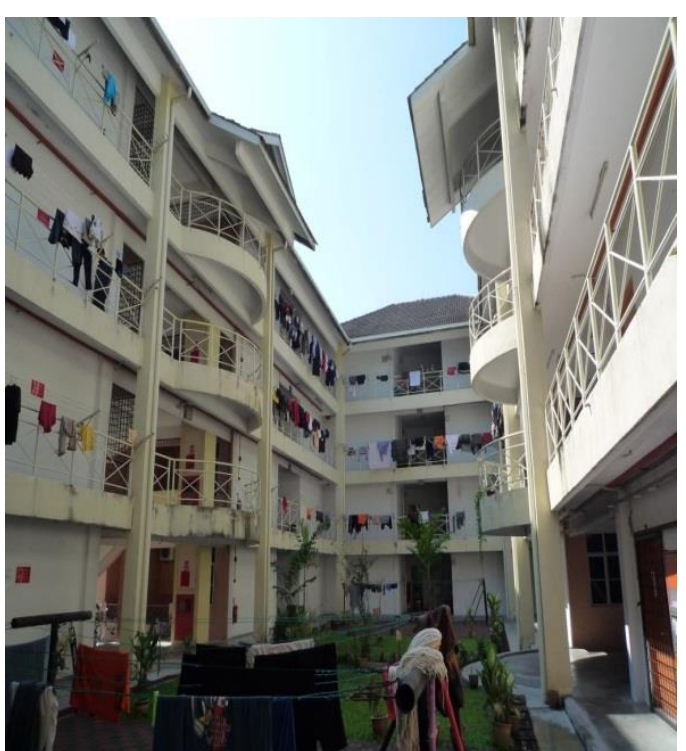

(b) Internal courtyard in the middle of residential building

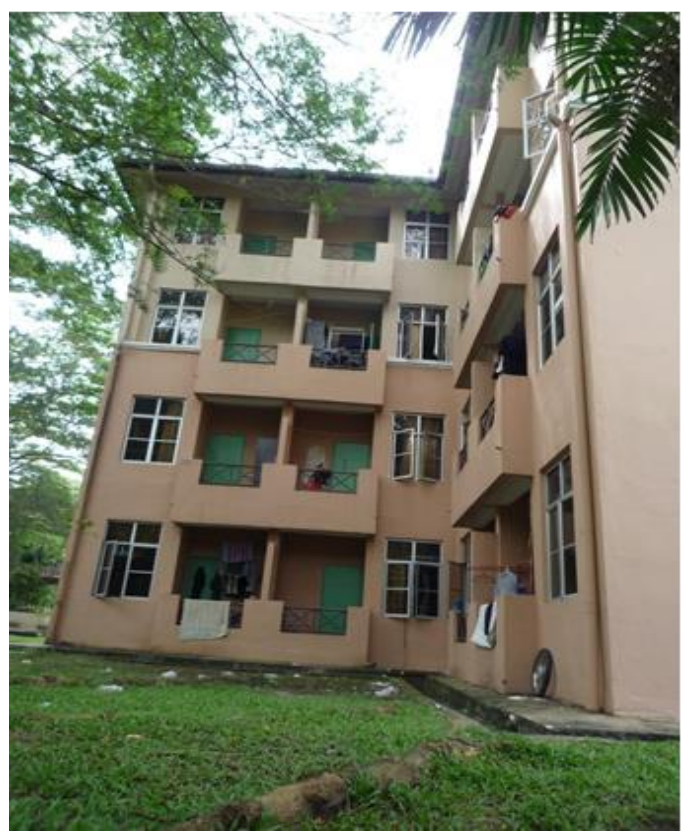

(c) Casement and turn window design with tinted glass and large balcony in each residential unit faces to outside areas

Figure 6: The characteristics of KD-2 


\section{RESULTS AND DISCUSSION}

A total of 266 responses retrieved were fully supplied by the respondents at the KD-1. The number of respondents exceeded the minimum number of feedbacks required for a reliable $95 \%$ confidence level and $\pm 5 \%$ margin of error from the overall population. The result of the satisfaction survey at KD-1 is presented in Table 1. Only 181 responses were fully filled in by the respondents at the KD-2. This number only exceeds the minimum number of respondents as relying on $85 \%$ confidence level and $\pm 5 \%$ margin of error from the overall population. The result of the satisfaction survey at KD-2 is presented in Table 2.

Table 1. Result of the satisfaction survey at KD-1

\begin{tabular}{lccccc}
\hline \multirow{2}{*}{$\begin{array}{l}\text { Performance } \\
\text { indicators }\end{array}$} & \multicolumn{5}{c}{$\begin{array}{c}\text { Likert scale / Residents' responses } \\
\text { (\%) }\end{array}$} \\
\cline { 2 - 6 } & $\mathbf{- 2}$ & $\mathbf{- 1}$ & $\mathbf{0}$ & $\mathbf{+ 1}$ & $\mathbf{+ 2}$ \\
\hline $\begin{array}{l}\text { Building layout } \\
\text { Overall quality } \\
\text { of the building }\end{array}$ & 0.4 & 8.7 & 28.7 & $\mathbf{5 0 . 2}$ & 12.1 \\
$\begin{array}{l}\text { Lighting quality } \\
\text { (natural daylight) }\end{array}$ & 4.2 & 12.0 & 34.4 & $\mathbf{4 0 . 9}$ & 8.5 \\
$\begin{array}{l}\text { Thermal comfort } \\
\text { and indoor air } \\
\text { quality }\end{array}$ & 3.4 & 11.7 & 29.7 & $\mathbf{4 3 . 6}$ & 11.7 \\
$\begin{array}{l}\text { Overall comfort } \\
\text { level }\end{array}$ & 0.8 & 4.5 & 29.1 & $\mathbf{5 3 . 6}$ & 12.1 \\
$\begin{array}{l}\text { Influence of } \\
\text { overall building } \\
\text { conditions on the } \\
\text { degree of work } \\
\text { productivity }\end{array}$ & & & & & \\
\hline
\end{tabular}

Table 2. Result of the satisfaction survey at KD-2

\begin{tabular}{lccccc}
\hline \multirow{2}{*}{$\begin{array}{l}\text { Performance } \\
\text { indicators }\end{array}$} & \multicolumn{5}{c}{ Likert scale / Residents' responses } \\
\cline { 2 - 6 } & $\mathbf{- 2}$ & $\mathbf{- 1}$ & $\mathbf{0}$ & $\mathbf{+ 1}$ & $\mathbf{+ 2}$ \\
\hline $\begin{array}{l}\text { Building layout } \\
\text { Overall quality } \\
\text { of the building }\end{array}$ & 6.6 & 12.2 & $\mathbf{4 2 . 0}$ & 31.5 & 7.7 \\
$\begin{array}{l}\text { Lighting quality } \\
\text { (natural } \\
\text { daylight) }\end{array}$ & 12.2 & 13.8 & 38.7 & $\mathbf{3 9 . 2}$ & 3.9 \\
$\begin{array}{l}\text { Thermal and } \\
\text { comfort and } \\
\text { indoor } \\
\text { quality air }\end{array}$ & 21.5 & 22.1 & $\mathbf{3 6 . 5}$ & 24.9 & 11.0 \\
$\begin{array}{l}\text { Overall comfort } \\
\text { level }\end{array}$ & 6.1 & 12.2 & $\mathbf{3 9 . 8}$ & 33.1 & 8.8 \\
$\begin{array}{l}\text { Influence of } \\
\text { overall building } \\
\text { conditions on } \\
\text { the degree of }\end{array}$ & & & & & \\
$\begin{array}{l}\text { work } \\
\text { productivity }\end{array}$ & & 11.0 & 27.6 & $\mathbf{3 9 . 8}$ & 16.0 \\
\hline
\end{tabular}

According to the percentage of figures in Table 1 , the majority of respondents at the KD-1 voted +1 for all six performance indicators. About $50.2 \%$ of respondents agreed that internal courtyard is a 'good' building layout and $52.1 \%$ 'satisfied' with the overall quality of the building. Regarding on the overall comfort level, $53.6 \%$ of respondents who represented the majority feel 'comfortable' with the building. They claimed that the quality of lighting, in terms of natural daylight in the building is 'bright' (40.9\%) with a 'good' $(43.6 \%)$ condition of thermal comfort and indoor air quality. Consequently, $49.4 \%$ claim that the degree of their work productivity has 'increased' considerably.

By referring to Table 2, different results were obtained on the residents' satisfaction survey at the KD-2. The majority of residents voted one rate lower for four performance indicators as compared to the responses given by the majority of residents at the KD-1. About $42.0 \%$ of respondents agreed that the internal courtyard is a 'fair' building layout; even $39.2 \%$ of respondents who represented the majority are 'satisfied' with the overall quality of the building. The same situation also recognised on the work productivity. About $39.8 \%$ claimed their work productivity has 'increased' even there was no decision made on the overall comfort level $(39.8 \%)$, including the quality of lighting $(36.5 \%)$ and the thermal comfort and indoor air quality $(28.7 \%)$. The majority of respondents voted for 'neither'.

The survey results of both residential colleges indicate that the satisfaction level of the residents is highly influenced by the arrangement and design of the internal courtyard. At the KD-1, the internal courtyard is facing most of the rooms directly, where the accessibility is not an issue to the residents especially for those who are living at the ground level. The gazebo as a social or engagement space for the residents, with the presence of shrubs and grass creates the internal courtyard that is fully functioning as a healing element while improving the thermal comfort of the building's environment (Almhafdy et al., 2013a; Ghaffarianhoseini at al., 2015).

A different situation can be seen at the KD-1, when all rooms are not directly facing the 
internal courtyard. There are only open corridors, which connect all cubicles, formed by four rooms facing each other. Thus, the internal courtyard is not fully utilised by the residents. The absence of transoms on top of the entrance door and wall limits the utilisation of natural ventilation and daylight in the room. This has been worsened by the modification of the internal courtyard by the residential college administration. The green ground of the internal courtyard in blocks C and D has been replaced with textured pavement and it has turned into a place to hang clothes for drying. In order to eliminate some of the weather elements from the space, a big polycarbonate roof was installed on the second floor of the building, as shown in Figure 7.

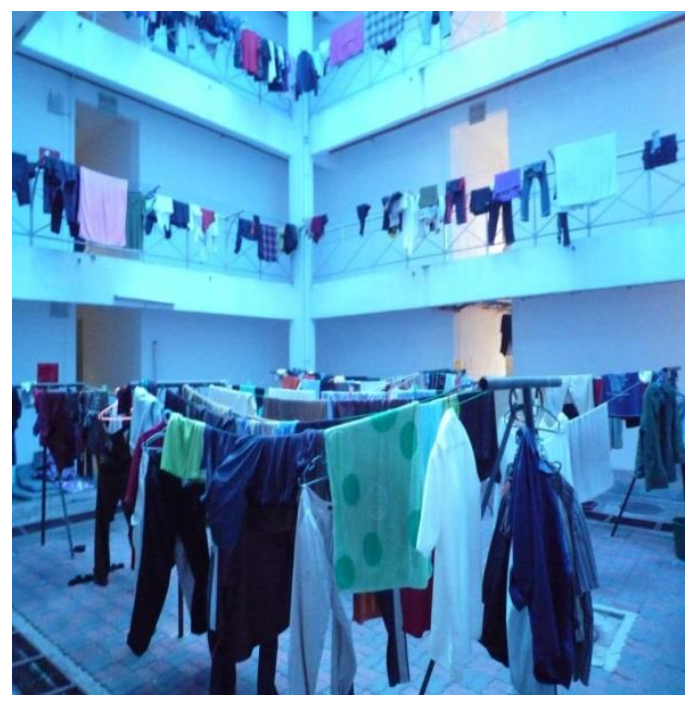

(a) Textured pavement

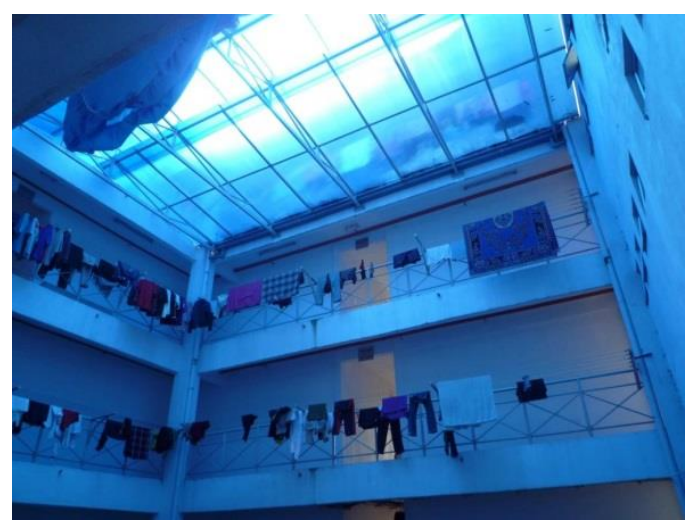

(b) a big polycarbonate roof

Figure 7: Modification on internal courtyard in blocks $\mathrm{C}$ and $\mathrm{D}$ at $\mathrm{KD}-2$

In order to increase the residents' satisfaction level, the modification of the internal courtyard should be done properly. The potential of the courtyard can be optimised, especially in the thermal performance if the particular design variants and configurations are known Ghaffarianhoseini at al., 2015; Almhafdy et al., 2013b). According to Murgul (2015), the accurate glazing of a courtyard is able to improve the quality of a courtyard space, especially on daylight and natural ventilation performance, increase the socialisation and interactions of dwellers, psychological relations with the natural environment and ensure the protection from negative environmental impacts. Moreover, the commercial attractiveness and market value of a building. By making a comparison, open courtyard buildings that are relevant in all climates exhibit a better energy performance for the shorter buildings and as the building height increases, at some point, the enclosed atrium exhibits a better energy performance (Aldawoud \& Clark, 2008). With regard to KD-2, which is designed with three-floor levels excluding a ground floor, the installation of the polycarbonate roof should highly be reconsidered with the building energy performance aspect.

Alternatively, the presence of the balcony in each room replaces the role of the internal courtyard as a social or engagement space to the residents at KD-2. The balcony improves view enjoyment by facing the wider outdoor landscape with diverse sceneries (Chan \& Chow, 2010). Thus, we need to provide the healing element efficiently with a better improvement of daylighting, thermal comfort and indoor air quality (Almhafdy et al., 2013a; Lechner, 2009; Mohamed et al., 2014). Moreover, it offers residents a provision of privacy to socialise, as it has been identified as a significant space for social gatherings that also acts as buffer zones of a gentle transition between the public and private spaces (Williams, 2005).

\section{CONCLUSION}

The location and condition of the internal courtyard in a building influence the satisfaction level of residents. The undeviating interaction between residents' room and internal courtyard allows for the transom on top of the entrance door and wall to fully function, in providing 'bright' natural daylight and 'good' natural ventilation in the room. The present of grass, shrubs and gazebo with easy accessibility make the internal courtyard conducive as a social engagement space. Indirectly improve the overall comfort level of the building and 'increased' the degree of work productivity of the residents. In contrast, the allusive interaction between resident's room and internal courtyard influenced the residents 
to vote 'fair/neither' for building layout, lighting quality, thermal comfort and indoor air quality and overall comfort level. Unfortunately, the majority of residents agreed that the overall quality of building layout which is designed with an internal and balcony is 'good' and 'increased' the degree of their work productivity. These findings indicate that the internal courtyard is relevant to be applied to the building design, particularly low-rise buildings in the equatorial climate region. The correct position and easy accessibility with a full adaptation of green landscape are the essential elements that should highly consider for improving daylighting and natural ventilation in the building.

For the future research, it is necessary to have a greater number of respondents to obtain an accurate result of the survey to represent the overall population; it should exceed the minimum number of feedbacks with a $95 \%$ confident level and $\pm 5 \%$ margin of error. The scope of study should be expanded by including more questions and buildings as a case study for better understanding the best design of an internal courtyard at low-rise residential buildings.

\section{ACKNOWLEDGEMENT}

The authors would like to thank Dayasari and Ungku Aziz Residential Colleges at the University of Malaya campus for their permission to carry out the survey. This analysis was financially supported by the Institut Pengurusan dan Pemantauan Penyelidikan (IPPP), the University of Malaya under BKP Grant (BK010-2015).

\section{REFERENCES}

Aldawoud, A. \& Clark, R. (2008). Comparative analysis of energy performance between courtyard and atrium in buildings. Energy and Buildings, 40(3), 209-214

Aldawoud, A. (2008). Thermal performance of courtyard buildings. Energy and Buildings, 40(5), 906-910

Almhafdy, A., Ibrahim, N., Ahmad, S. S., \& Yahya, J. (2013a). Analysis of courtyard functions and its design variants in the Malaysian hospital. Procedia Social Behavorial Sciences, 105, 171-182

Almhafdy, A., Ibrahim, N., Ahmad, S. S., \& Yahya, J. (2013b). Courtyard design variants and microclimate performance. Procedia Social Behavorial Sciences, 101, 170-180

Almhafdy, A., Ibrahim, N., Ahmad, S. S., \& Yahya, J. (2015). Thermal Performance Analysis of Courtyards in a Hot Humid Climate using Computational Fluid Dynamics CFD Method, Procedia Social Behavorial Sciences, 170, 474-483

Chan, A. L. S., \& Chow, T. T. (2010). Investigation on energy performance and energy payback period of application of balcony for residential apartment in Hong Kong. Energy and Buildings, 42(12), 2400-2405

Ghaffarianhoseini, A., Berardi, U., \& Ghaffarianhoseini, A. (2015). Thermal performance characteristics of unshaded courtyards in hot and humid climates. Building and Environment, 87, 154-168

Hadjri, K., \& Crozier, C. (2009). Postoccupancy evaluation: Purpose, benefits and barriers. Facilities, 27(1/2), 21-33

Hassanain, M. A. Sedky, A., Adamu, Z. A., \& Saif, A. (2010). A framework for quality evaluation of university housing facilities. Journal of Building Appraisal, 5(3), 213-221

Ilesanmi, A. O. (2010). Post-occupancy evaluation and residents' satisfaction with public housing in Lagos, Nigeria. Journal of Building Appraisal, 6(2), 153-169

Jamaludin, A. A., Keumala, N., Ariffin, A. R. M. \& Hussein, H. (2014). Satisfaction and perception of resident towards bioclimatic design strategies: Residential college buildings. Indoor and Built Environment, 23(7), 933-945

Khalil, N., Husin, H. N., Nawawi, A. H., \& Hashim, A. E. (2008). Post occupancy evaluation for performance evaluation of building facilities in higher education buildings. Paper presented at 9th International Conference SENVAR \& 2nd ISESEE.

Lechner, N. (2009). Heating, cooling, lighting: Sustainable design methods for architects. New Jersey: John Wiley \& Sons

Mohamed, M. F., King, S., Behnia, M., \& Prasad, D. (2014). The effects of balconies on the natural ventilation performance of cross-ventilated highrise buildings. Journal of Green Building, 9(2), 145-160 
Murgul, V. (2015). Reconstruction of the Courtyard Spaces of the Historical Buildings of Saint-Petersburg with Creation of Atriums. Procedia Engineering, 117, 808-818

Ogunjuyigbe, A. S. O., Ayodele, T. R. , \& Akinola, O. A. (2017). User satisfaction-induced demand side load management in residential buildings with user budget constraint. Applied Energy, 187, 352-366.

Preiser, W. F. E. (1995). Post-occupancy evaluation: How to make buildings work better. Facilities, 13(11), 19-28

Sadafi, N., Salleh, E., Haw, L. C., \& Jaafar, Z. (2011). Evaluating thermal effects of internal courtyard in a tropical terrace house by computational simulation. Energy and Buildings, 43(4), 887-893

Safarzadeh, H., \& Bahadori, M. N. (2005). Passive cooling effects of courtyards. Building and Environment, 40(1), 89-104

Shafaghat, A., Keyvanfar, A., Majid, M. Z. A., Lamit, H., Ahmad, M. H., Ferwati, M. S., \& Ghoshal, S. K. (2016). Methods for adaptive behaviors satisfaction assessment with energy efficient building design. Renewable and Sustainable Energy Reviews, 57, 250-259.

Shahzad, S. S., Brennan, J., Theodossopoulos, D., Hughes, B., \& Calautit, J. K. (2017). Energy and comfort in contemporary open plan and traditional personal offices. Applied Energy, 185(Part2), 1542-1555.

Turpin-Brooks, S., \& Viccars, G. (2006). The development of robust methods of post occupancy evaluation. Facilities, 24(5/6), 177-196

Williams, J. (2005). Designing neighbourhoods for social interaction: The case of cohousing. Journal of Urban Design, 10(2), 195-227

Yamane, T. (1967). Statistic, an introductory analysis. New York: Harper \& Row

Zakaria, M. A., Kubota, T., \& Toe, D. H. C. (2015). The effects of courtyards on indoor thermal conditions of Chinese shophouse in Malacca. Procedia Engineering, 121, 468-476 